\title{
SAMORZĄD TERYTORIALNY A ADMINISTRACJA RZĄDOWA - ADMINISTROWANIE W WARUNKACH NIEPEWNOŚCI
}

Rok 2020 staje się symbolem występujących nagle zagrożeń zmieniających zasadniczo życie społeczne i gospodarcze ${ }^{1}$. Wśród wielu autorów panowało jednak początkowo przekonanie, że jest to sytuacja nadzwyczajna, po której ustapieniu zarówno gospodarka, jak i administracja powróca do stanu poprzedniego - oczywiście z koniecznościa nadrobienia powstałych strat. Równocześnie postępujące zmiany klimatyczne, niestabilność geopolityczna, zapowiadana druga fala pandemii i postpandemiczny kryzys gospodarczy skłaniają do zweryfikowania tego założenia ${ }^{2}$. Należy raczej przyjąć, że wchodzimy w okres powtarzających się i nawarstwiających niepewności, które w różnej postaci będą powracać, silnie wpływając zwłaszcza na sposób, zakres i formy działania wszystkich aktorów systemu ${ }^{3}$. Sa to czynniki niezależne od nas. Należy więc zastanowić się, czy istnieje możliwość takiej organizacji administracji publicznej i takich zmian w legislacji, które będa sprzyjać zwiększeniu odporności państwa jako całości na wstrząsy i większej elastyczności jego działania ${ }^{4}$.

Jeżeli więc przyjąć do wiadomości, że wchodzimy w okres nawarstwiających się, a czasem wręcz kaskadowych stanów niepewności, należy także rozważyć, jakie zasady jego funkcjonowania będą sprzyjać redukcji stanu niepewności i zapewnieniu ciagłości działania władzy i administracji publicznej. Sa tu możliwe trzy podejścia.

Zgodnie z pierwszym $\mathrm{z}$ nich narastające zagrożenia wymagają silnego państwa, scentralizowanego kierownictwa, koncentracji zasobów, zwiększenia odpowiedzialności funkcjonariuszy publicznych i jej pryncypialnego egzekwowania. Według tej koncepcji fundamentalne jest udrożnienie kanałów informacyjnych oraz rozbudowanie struktur doradczych na szczeblu centralnym dla zapewnienia szybkiego i sprawnego reagowania. Wizja silnego, twardego państwa ma stanowić adekwatną odpowiedź na stan rosnącej niepewności. Władza w tym modelu jest silnie reaktywna, reaguje na bodźce z otoczenia, przez często i spektakularnie zmieniane pod ich wpływem pra-

\footnotetext{
${ }^{1}$ Por. zwłaszcza globalna perspektywę ONZ w opracowaniach UNU.

${ }^{2}$ Pegram (2020).

${ }^{3}$ Crozier, Friedberg (1982): $4 \mathrm{n}$.

${ }^{4}$ Łukasiewicz (2006): 86-88.
} 
wo, a nie długofalowe, powstające w partnerstwie publicznym plany legislacji i polityki publiczne ${ }^{5}$.

Przy drugim podejściu (zwolenników państwa minimalnego) ważne jest umocnienie obywateli i podmiotów gospodarczych oraz rozbudowa sieci współdziałania z nimi w warunkach zagrożenia. Ciężar adekwatnej reakcji ma spoczywać na przedsiębiorczych obywatelach, organizacjach pozarządowych i wielkich podmiotach gospodarczych, w tym na silnych korporacjach. Rola państwa jest zapewnianie sieci współpracy, komunikacji i uruchamianie zasobów w sytuacjach kryzysowych i tylko w takich sytuacjach administracja publiczna, korzystając z władczych instrumentów działania, może mobilizować zasoby gospodarcze i społeczne ${ }^{6}$.

Według trzeciej koncepcji ${ }^{7}$ ważne jest istnienie współpracującego systemu administracji rządowej i samorządowej, a w ich ramach swoistych niezależnych modułów zdolnych do samodzielnej reakcji, często w niestandardowych warunkach zagrożenia działających kreatywnie, wdrażających innowacje społeczne. W takim ujęciu - zgodnym z zasada pomocniczości i decentralizacją - wielką rolę odgrywa koordynacja ${ }^{8}$, przekazywanie doświadczeń ze szczebli podstawowych do szczebli wyższych. Państwo reagujące elastycznie, w zróżnicowany sposób, w zależności od zagrożenia dobra wspólnego na poszczególnych częściach terytorium może zapewnić działanie bardziej efektywne oszczędzające skape, ograniczone zasoby, działając stale w porozumieniu z miejscową ludnościa.

Spójrzmy na reakcję aparatu państwowego w warunkach pandemii. Pierwsze działania obejmowały jednolite regulacje dla całego terytorium kraju. W miarę trwania pandemii następowała racjonalizacja i dywersyfikacja działań, odmienne obostrzenia w poszczególnych jednostkach podziału terytorialnego w zależności od stanu i prognozy zachorowań. Obecna dzienna liczba zachorowań jest dużo większa niż w początkach epidemii (chociaż w istocie rzeczy obiektywnie trudna jest ta liczba do zweryfikowania), jednak reakcja państwa nie jest słabsza, ale dużo bardziej zróżnicowana. Czy w każdym kolejnym nowym stanie zagrożenia będziemy jednak mogli pozwolić sobie na wielomiesięczny proces prób i błędów, na uczenie się „na żywym organizmie” społecznym? Czy państwo nie powinno być w swoich strukturach administracyjnych elastyczne, a równocześnie odporne na nieoczekiwane zmiany, zachowujące spójność społeczną w działaniu i dobrą komunikację między szczeblami administracji publicznej, a równocześnie pozwalające wykorzystać znajomość warunków miejscowych, indywidualną inicjatywę i kreatywność dostosowana do warunków?

Administracyjnoprawna analiza działania administracji publicznej w sytuacji kryzysowej nawałnicy w Borach Tucholskich wykazała bardzo dobre przygotowanie podstawowych jednostek samorządu terytorialnego oraz inspekcji

\footnotetext{
${ }^{5}$ Ewolucja doktryny por. Kasiński (2009): 11-30, 189 n.

${ }^{6}$ Mager (2008): 370-381.

${ }^{7}$ Dolnicki (2019); Sługocki (2012): 56-63, 198-207.

${ }^{8}$ Stankiewicz (2019).
} 
i straży działających na szczeblu powiatu. Autorka tej analizy konstatuje jednak niepełną decentralizację w zarządzaniu kryzysowym, zwłaszcza ograniczoną na obszarze województwa. Wykonywanie zadań od pewnego momentu przybiera postać działań scentralizowanych, tylko częściowo łagodzonych dekoncentracją. Charakterystycznym ustaleniem było wystapienie blokady udzielenia pomocy przez siły zbrojne właśnie - co nieoczekiwane - ze względu na całkowite scentralizowanie decyzji. Całkowicie sprawdziła się w tamtych warunkach wzorowa partycypacja społeczna. Charakterystyczna była także diagnoza paraliżu zbiurokratyzowanego systemu ostrzegawczego i niewystarczających działań wojewody ${ }^{9}$. Czy wystarczy jednak po prostu poszanowanie zasady pomocniczości oraz daleko posunięta decentralizacja, aby określić państwo jako elastyczne i odporne, zdolne do funkcjonowania w warunkach rosnącej niepewności? Przecież równocześnie akceptuje się w doktrynie dekoncentrację jako najlepsze rozwiązanie w przypadku służb ratunkowych, stanów i sytuacji nadzwyczajnych. Ważną rolę muszą odegrać odpowiednio zaprojektowane struktury i procedury uwzględniające profilaktykę i przygotowanie do stanu kryzysowego ${ }^{10}$. Przy dominacji zasady decentralizacji współistniejąca dekoncentracja w administracji rządowej jest naturalnym rozwiązaniem, zwłaszcza w administrowaniu ryzykiem i przeciwdziałaniu sytuacji kryzysowej. Nie zmienia ona elastycznego działania państwa jako całości.

Należy odpowiedzieć na pytanie, czy obecny ustrój administracji publicznej, podstawy prawne jego działania, system finansowania w tym miejsce samorządu terytorialnego odpowiadają istniejacym zadaniom, a zwłaszcza prognozowanemu spiętrzeniu sytuacji kryzysowych, nadzwyczajnych.

Jak wskazano w literaturze podsumowującej 30 lat działania samorządu terytorialnego w Polsce, podstawowy ustrój samorządu terytorialnego okazał się dość odporny na szereg dotychczasowych nagłych wyzwań. Do takich wielkich wyzwań należała zarówno tzw. powódź tysiąclecia we Wrocławiu, jak i kryzys gospodarczy w roku 2008, czy też otwarcie granic lub masowe bankructwa zakładów przemysłowych na początku lat dziewięćdziesiątych i wszystkie te wyzwania przyjęy na siebie przede wszystkim jednostki samorządu terytorialnego, ich prosta, czytelna struktura i zdolność szybkiego reagowania, silna legitymacja społeczna oraz zdolności mediacyjne wyrastające z zaufania społecznego pozwoliły im na elastyczną reakcję.

Dużo bardziej krytyczne są ustalenia doktryny dotyczące podstaw prawnych funkcjonowania samorządu terytorialnego. Można wręcz na podstawie istniejacych analiz stwierdzić, że podstawy prawne tego systemu określone w obrębie konstytucyjnej zasady decentralizacji i pomocniczości są w poważnym stopniu naruszane i poddawane planowej erozji. Gruntowne analizy stanu prawnego dokonane przykładowo przez Bogdana Dolnickiego ${ }^{11}$, Barbarę

${ }^{9}$ Kierzkowska (2019): 373 n., 391-392. Por. Dziuban (2019): 529 n. oraz diagnozowana tam inspekcja sanitarna, analizowana w przeddzień wybuchu pandemii; Wituska (2019): $661 \mathrm{n}$.

10 Matan (1996): $17 \mathrm{n}$.

11 Dolnicki (2019a); (2019b). 
Jaworską Dębską ${ }^{12}$ czy Krystiana Ziemskiego ${ }^{13}$, a także Jerzego Korczaka ${ }^{14}$ podczas kolejnych konferencji naukowych poświęconych samorządowi terytorialnemu wskazują dokonywane za pomoca kolejnych zmian ustawowych odchodzenie od decentralizacji w kierunku recentralizacji. Konferencje teoretyczne dotyczące samorządu terytorialnego odbywające się np. w Łodzi, Katowicach i w Krakowie sa poświęcone analizie już nie tyle konstytucyjnie przewidzianemu fenomenowi decentralizacji, ile recentralizacji administracji publicznej.

Zmiana podstaw prawnych działania samorządu terytorialnego w ostatnich latach nie ma charakteru całościowego i spójnego. Oznacza raczej liczne wyrywkowe zmiany prowadzące do pewnego stanu niepewności, a nawet chaotycznych, kolejno poprawianych przepisów. Poza głównym kierunkiem recentralizacji - trudno jednak ustalić nowe kierunkowe zasady dokonywanych zmian. Nową propozycją teoretyczna, która pojawiła się ostatnio, była co prawda propozycja deglomeracji, nie wnosi ona jednak zasadniczo nic nowego do ustroju samorządu terytorialnego, zmienia tylko miejsce wykonywania zadań publicznych. Deglomeracja ${ }^{15}$ jako techniczne rozproszenie wykonywania zadań publicznych przez lokowanie urzędów centralnych w mniejszych miejscowościach może mieć znaczenie przykładowo dla ograniczenia depopulacji mniejszych miejscowości na Mazowszu, nie stanowi jednak zmiany jakościowej w ustroju administracji rządowej i samorządu terytorialnego. Ulokowanie prestiżowego, ale wyspecjalizowanego urzędu wymusiłoby tylko kosztowne ekologicznie dojazdy pracowników, a nadzieje z nią związane wydają się nadmierne. Gdyby jednak deglomeracja została zastosowana w sposób planowy (jako środek) restrukturyzacji starego regionu przemysłowego, jakim jest Łódź, i nadanie jej części waloru stołeczności przez przeniesienie tam części siedzib np. gospodarczych resortów oraz instytucji centralnych po to, aby na skrzyżowaniu głównych autostrad stworzyć nowoczesne centrum zarządzania gospodarka - miałoby to zasadnicze znaczenie dla regionu. Taka duopolis z Warszawą nie byłaby niczym nowym we współczesnym świecie i sprzyjałaby unowocześnieniu centrum kraju. Część inwestycji infrastrukturalnych poczynionych już w Łodzi sprzyjałaby takiemu rozwojowi ${ }^{16}$. Z kolei Warszawa odciążona komunikacyjnie od interesantów resortów gospodarczych w sytuacji istnienia nowoczesnych elektronicznych środków łączności nie ucierpiałaby jako centrum polityczne i administracyjne kraju.

Fundamentalne znaczenie dla sprawności działania administracji publicznej ma ustrój administracji rządowej zarówno na poziomie centralnym, jak i terenowym. Również na tle europejskim sytuację w Polsce cechuje zdumie-

12 Jaworska-Dębska (2019): 202 n.

13 Ziemski, Karciarz (2019): $131 \mathrm{n}$.

14 Korczak (2019):192 n.

15 Krawczyk (2019): 49-51; 61. Autor wskazuje przede wszystkim, że deglomeracja nie służy wcale przenoszeniu zadań bliżej jednostki, a raczej jest „instrumentem agregacji środków bliżej jednostek".

${ }^{16}$ Koncepcja warszawsko-łódzkiego związku metropolitalnego pojawia się w piśmiennictwie. Zob. więcej: Szlachetko (2020). 
wająca asymetria: o ile samorząd terytorialny gruntownie zmieniony, przywrócony 30 lat temu był od tego czasu poddawany kolejnym reformom i udoskonalaniu (do których trudno zaliczyć ostatnie zmiany recentralizacyjne), o tyle administracja rządowa mimo niewielkich zmian początkowych przeżyła jedynie dwie zasadnicze reformy, z których jedna została już praktycznie odwrócona. To, po pierwsze - ustawa o działach administracji rządowej, a po drugie - wprowadzenie systemu służby cywilnej (poddanej ostatnio zasadniczym zmianom $)^{17}$. Mimo istnienia ustawy o działach administracji rządowej ${ }^{18}$, która zwiększyła swobodę Prezesa Rady Ministrów w komponowaniu składu rządu i przydzielaniu poszczególnym członkom Rady Ministrów zakresu zadań i kompetencji w samej strukturze działania resortu - niewiele się zmieniło. Podstawowa jednostką organizacyjną pozostaje departament, a pozycję rzeczywista tych jednostek można dostrzec nawet w wynagrodzeniu dyrektorów departamentów (czasem znacząco wyższym niż wynagrodzenie wiceministra). System departamentów i ich struktura zostały stworzone w latach pięćdziesiątych według jednego jednolitego - narzuconego przez Moskwę wszystkim ówczesnym tak zwanym krajom socjalistycznym - wzoru. Oczywiście podział na resorty i departamenty wywodził się z kolei z przejętej przez administrację rosyjską organizacji pruskiej biurokracji.

Należy zwrócić uwagę, że od tego czasu minęła już praktycznie cała epoka, a struktura resortów (i to często kluczowych resortów polskiej administracji publicznej) pozostaje praktycznie niezmieniona. Tworzone także były nowe resorty, np. cyfryzacji czy klimatu, mają one jednak dość krótki żywot. W okresie działania różnych rządów występuje zmniejszenie i zwiększenie liczby resortów, łączenia ich w większe jednostki. Jedno i drugie w odbiorze społecznym ma łączyć się z oszczędnościami i racjonalizacją działania administracji publicznej albo wręcz hasłem taniego państwa ${ }^{19}$.

Należy rozważyć, co może zrobić minister i jego resort w sytuacji, gdy nagłe zagrożenie dotyczy spraw znajdujących się w zakresie działania, za które ponosi odpowiedzialność. Przykładem takiego zagrożenia może być ostatnia, trwająca wciąż jeszcze pandemia COVID-19. Niewątpliwe jest nagłe zwiększenie zadań i obciążeń resortu, zwłaszcza jednostek państwowej inspekcji sanitarnej, większe obciążenie zadaniami istniejących pracowników, zwiększone potrzeby finansowe, konieczność szybkich, punktowych interwencji wymagających alokacji dodatkowych środków i zasobów ${ }^{20}$. Wszystko to próbuje się zapewnić ustawami epizodycznymi, nowelizacją budżetu. Nie ma jednak w naszym systemie z góry zaprogramowanych możliwości przesunięcia części kadr do załatwiania większej ilości decyzji administracyjnych, postanowien,

17 Sługocki 432-435

18 Ustawa z 4 września 1997 r. o działach administracji rządowej (t.jedn.: Dz. U. 2020, poz. 1220 ze zm.).

19 Zob. także: Krawczyk (2019): 48 n.; Mażewski, (2020): 7 n.

${ }_{20}$ Por. przykładowo J. Caban-Korbas w wywiadzie o słabości kadrowej powiatowych struktur inspekcji sanitarnej i jej wieloletnim marginalizowaniu oraz likwidacji laboratoriów epidemiologicznych, redukacji etatów; Biela (2020). 
rozporządzeń i zarządzeń, czy wreszcie wytycznych, instrukcji oraz poleceń służbowych w sferze wewnętrznej.

Struktura departamentów jest sztywna. Oddelegowanie pracowników zajmuje czas, wymaga szeregu dodatkowych czynności, ale jest możliwe w ramach resortu. Sięgnięcie po dodatkowych pracowników spoza resortu, w ramach e-administracji, na czas określony, jest niezwykle utrudnione. Jedynym resortem, w którym przewidziano zwiększone zapotrzebowanie na personel w nagłych przypadkach, jest resort spraw zagranicznych, a w przeszłości ministrowie odpowiedzialni za integrację europejska. Instytucja tzw. kangurów, a więc urzędników delegowanych krótkoterminowo, w związku z nagłymi potrzebami administracyjnymi (np. w związku z prezydencją Polski w Unii Europejskiej) ma bardzo ograniczony zasięg.

Oczywiście podstawową ramą prawnego działania administracji powinno być korzystanie z konstytucyjnej regulacji stanów nadzwyczajnych. Ustawy „covidowe”21 przyniosły ogromna ilość zmian materialnoprawnych. Brak było jednak instytucjonalnego zwiększenia zatrudnienia, np. na okres 2 lat w resorcie zdrowia, w ściśle określonych obszarach. Można przewidzieć w najbliższych miesiącach zwiększone potrzeby kadrowe również $\mathrm{w}$ innych resortach bezpośrednio związanych ze zdalnym nauczaniem czy telemedycyna. Sztywna i krucha struktura administracji centralnej wymusza łatanie w takich przypadkach powstających wakatów często na granicy prawa. Zamiast zmiany istoty tej sytuacji pojawiły się raczej dążenia do zwolnienia z odpowiedzialności za bezprawie legislacyjne. Skoro przyjmujemy, że powtarzajace się zagrożenia, nagłe kryzysy wymagają elastycznej i niestandardowej reakcji, a z drugiej strony nowoczesne technologie pozwalająjuż korzystać (tak jak ze zdalnej edukacji i telemedycyny) ze zdalnej administracji - należałoby umożliwić istnienie w administracji centralnej zasobu kadrowego, rezerwy na takie właśnie nagłe przypadki.

Sztywna struktura departamentów, referatów i stanowisk jest już całkowicie archaiczna. Powstała w okresie technologii ręcznego, a najwyżej mechanicznego przetwarzania danych ${ }^{22}$. Stan prawny dotyczacy struktury i funkcjonowania administracji centralnej ignoruje nie tylko zmiany natury narastających zagrożeń, ale także dokonującą się, mimo wszystkich przeszkód, transformację cyfrowa. Archaiczny aparat administracji centralnej nie może dobrze współpracować z „młodszą” i bardziej nowoczesną strukturą samorządu terytorialnego. Nie sprzyja jej modernizacji, raczej hamuje jej zmiany, opóźnia wprowadzanie standardów działania ${ }^{23}$ sprzyjajacych obiektywizacji odpowiedzialności.

21 Ustawa z 2 marca 2020 r. o szczególnych rozwiązaniach związanych z zapobieganiem, przeciwdziałaniem i zwalczaniem COVID-19, innych chorób zakaźnych oraz wywołanych nimi sytuacji kryzysowych (Dz. U. poz. 374) z licznymi nowelizacjami.

${ }_{22}$ Por. J. Bondar, rzecznik GIS w wywiadzie prasowym: „Najważniejszy jest projekt digitalizacji państwowej inspekcji sanitarnej, prowadzony we współpracy z Ministerstwem Cyfryzacji, w celu udoskonalenia pracy jednostek inspekcji poprzez stworzenie elektronicznych narzędzi generujących rozmaite dokumenty, które dziś trzeba tworzyć ręcznie, i stworzenie nowoczesnych systemów łączności”. Biela (2020).

${ }^{23}$ Szerzej: Lipowicz (2019): 230 n. 
Wracając do początkowego postawienia problemu trzech możliwych scenariuszy (państwo scentralizowane, państwo minimalne, państwo elastyczne i współpracujące) wobec powtarzających się zagrożeń i potrzeby budowania państwa odpornego na wstrząsy, możemy stwierdzić, że znajdujemy się wciąż w obrębie pierwszego modelu. Wyobrażenie o silnym, twardym państwie, centralizowanie jego zasobów i działań w sytuacji zdecentralizowanego charakteru zagrożeń daje pozory siły, ale w rzeczywistości zmniejsza odporność na wstrzasy. Dobrym przykładem takiego postępowania była recentralizacja instytucji sanepidu w przeddzień pandemii oraz koncepcja centralizacji składnic materiałów przeciwpowodziowych do trzech wielkich składnic w skali kraju.

W obecnej sytuacji ciężar bieżącej walki z pandemią od strony administracyjnej spoczywa właśnie na stacjach sanitarno-epidemiologicznych. Naturalnym sposobem działania i elementem polityki administracyjnej powinno być $\mathrm{w}$ takiej sytuacji radykalne zwiększenie zatrudnienia i budżetów tych jednostek, wzmocnienie w systemie „kangurów” pracowniami e-administracji, a $\mathrm{w}$ porozumieniu z operatorami sieci telekomunikacyjnych natychmiastowe otwarcie, w drodze działania publicznoprawnego, nowych infolinii dla obywateli. Narastają sygnały, że osoby podejrzewające u siebie zakażenie albo bezradne w kwestii koniecznej samoizolacji, albo wreszcie oczekujące na wyniki testów przez kilka dni nie mogą połączyć się ze stacjami sanepidu. Terenowa administracja rządowa w obrębie inspekcji sanitarnej działała tu z ogromnym poświęceniem, ale całkowicie rutynowo, pozbawiona właściwego wsparcia centrum $^{24}$. Wsparcie to nie mogło także nadejść, jak oczekiwano, z samorządu terytorialnego, ponieważ, jak wspomniano wyżej, poddano je właśnie recentralizacji, całkowicie zmieniając dotychczasowe znaczenie zwierzchnictwa w zakresie służb, inspekcji i straży.

Z obawą można więc oczekiwać przykładowo wielkiej powodzi w sytuacji podobnej recentralizacji administracji wodnej (PGW Wody Polskie) ${ }^{25}$ oraz ewentualnego kryzysu zaopatrzenia w energię (blackout) oczekiwanego w najbliższych latach.

Aby nie ograniczać się do uwag krytycznych - spróbujmy na tym ostatnim przykładzie przedstawić, jak mogłaby wyglądać reakcja państwa zorganizowanego według trzeciego modelu, a więc ściśle współpracujących z administracją rządową niezależnych modułów samorządowych otwartych na innowacje społeczne i reagujących elastycznie na zagrożenia, dywersyfikujące swoje

${ }^{24}$ Molga (2020): „900 przypadków zachorowań dziennie nie wyrabiają się z praca. [...] Inspektorzy nalegaja, aby ruszył elektroniczny system generowania dokumentacji o kierowaniu na kwarantannę i do nadzoru epidemicznego. [...] W Małopolsce system już się posypał. Osoby zakażone koronawirusem lub z podejrzeniem choroby nie dodzwonią się do sanepidu i będą pozostawione same sobie. Mnożą się błędy, po których rodziny są więzione na 50-dniowej kwarantannie. [...] Jan Bondar, rzecznik prasowy Głównego Inspektoratu Sanitarnego, potwierdza w rozmowie z Wirtualną Polska, że po wzrostach zakażeń sytuacja w sanepidach jest bardzo trudna. [...] Pracownicy z pierwszej linii faktycznie są już wyczerpani. Obsłużyliśmy dokumentację o kwarantannie i nadzorze epidemiologicznym dla około 3 mln Polaków. Błędy? Przy tej skali musiały pojawić się wpadki - mówi Jan Bondar. Podkreśla, że wiele zarzutów związanych z funkcjonowaniem systemu zwalczania epidemii nie jest związanych z inspekcją sanitarna”".

${ }^{25}$ Kruś (2019): 622-627. 
działania. Oznaczać by to miało, po pierwsze, pakiet działań wyprzedzajacych, wielką akcję informacyjną obejmująca scenariusze ewakuacji osób szczególnie zagrożonych do centrów bezpieczeństwa energetycznego utworzonych w partnerstwie publiczno-prywatnym z podmiotami gospodarczymi, wojskiem i straża pożarna, przy czym głównym operatorem takich centrów powinna być Państwowa Straż Pożarna ${ }^{26}$. Umowy administracyjne ze spółdzielniami mieszkaniowymi i wspólnotami mieszkaniowymi, zwłaszcza w przypadku budynków o wysokiej zabudowie, gdzie w razie blackoutu przestaną działać windy, oświetlenie, a także ogrzewanie i dostawa wody, przewidywałyby kaskady działań. Szczególną rolę należy przewidzieć dla samorządu osiedlowego posiadającego rozeznanie w potrzebach mieszkańców. To tylko przykłady niezbędnych działań, które muszą być uzupełnione czynnościami faktycznymi, $\mathrm{np}$. zapewnieniem mobilnych jednostek zaopatrzenia w energię o charakterze komplementarnym (solarnym). Niezbędne byłoby także okresowe przeprowadzenie symulacji komputerowych i ćwiczeń, nawet w jednej dzielnicy wielkiego miasta. Gmina i powiat powinny dysponować kompletem przygotowanych aktów prawa miejscowego oraz wzorami decyzji administracyjnych niezbędnych do wydania w takim przypadku.

Jak wskazano $\mathrm{w}$ doktrynie prawa administracyjnego, ostatnie 30 lat rozwoju samorządu terytorialnego uruchomiło wielki potencjał partycypacji społecznej, niewykorzystany w pełni w obecnym stanie prawnym ${ }^{27}$.

Czasy sztywnej rutynowej administracji, działającej wyłącznie w swoich własnych ramach, w sposób władczy, jednostronny, nieodwołanie przemijaja. Transformacja cyfrowa i społeczeństwo sieci otwierają ogromne możliwości współpracy w takich sytuacjach kryzysowych, w których sieć ta może działać. Należy jednak dysponować alternatywna, przygotowaną siecią współpracy, nawet w przypadku blokady sieci internetowej.

W sytuacji, w której brak było skutecznej całościowej reprezentacji samorządu ${ }^{28}$, coraz większą rolę odgrywały organizacje reprezentujace miasta, powiaty, gminy, metropolie, starajace się o aktywne uczestnictwo w procesie legislacyjnym. Trudno jednak mówić o reprezentowaniu przez nie całości zróżnicowanego samorzadu terytorialnego. Brak konsultacji planowanych rozwiazań legislacyjnych w warunkach zagrożenia i kryzysu jest nieodłącznym elementem prognozowanych i znanych już błędów regulacji. Dopiero w sytuacji pandemii w sposób niespotykany wcześniej możemy obserwować zderzenie racji i interesów lokalnych, regionalnych i ogólnopaństwowych. Można postawić tezę, że brak instytucjonalnej reprezentacji całości jednostek samorządu terytorialnego w Polsce jest jednym z głównych nierozwiązanych problemów reformy ustrojowej lat dziewięćdziesiątych XX w. Ten ogromny deficyt, jak można sądzić, doprowadził do powrotu idei Senatu RP jako izby samorządowej. Jest to typowy przykład tzw. osieroconych kompetencji. Jak wskazano podczas

\footnotetext{
${ }^{26}$ Patrz także: Cieślak (2020): 42 n.

27 Jaworska-Dębska (2020); Szlachetko (2017); Florkowski (2019).

28 Przedańska, Szwast (2019): 165 n.
} 
krakowskiej konferencji samorządu terytorialnego ${ }^{29}$, pewna forma tej koncepcji może być połączona zarówno z zasadą trójpodziału władz, jak i z obecnym konstytucyjnym modelem miejsca samorządu terytorialnego w ustroju władzy publicznej. Jak wskazuje Jowanka Jakubek-Lalik, debata samorządu powinna koncentrować się na umocnieniu samorządu w relacjach z centrum oraz na uwzględnieniu wspólnot lokalnych jako współdecydentów i aktorów zarządzania publicznego ${ }^{30}$. Władze publiczne jednostek samorządowych maja jednak konstytucyjne prawo przynajmniej do konsultacji wprowadzanych radykalnych, władczych środków oddziaływania na terenie swoich jednostek. Brak takiej wyprzedzającej konsultacji wywołuje bowiem realne szkody, które powinny być rekompensowane jednostkom samorządu terytorialnego. Nie można argumentować, że mają one charakter losowy, żywiołowy, ponieważ chodzi o te szkody, które wystapiły tylko i wyłącznie w zawiązku z elementem zaskoczenia, brakiem możliwości przegrupowania sił, przygotowania ludności do uruchomienia szerokich akcji społecznych. Jeżeli samorząd terytorialny jest podmiotem władztwa publicznego na swoim terytorium, ma prawo nawet w obszarze, w którym władza centralna z usprawiedliwionych powodów może narzucić władcze działania, przynajmniej do konsultacji i informacji.

Rozważmy dotychczasowe doświadczenia informacyjnych kampanii społecznych prowadzonych w związku z pandemią. Nie można zarzucić administracji rządowej, ministrowi zdrowia i inspekcji sanitarnej zaniechania takich akcji informacyjnych. Prowadzone one były także w ramach mediów publicznych. Przeważają jednak, opisując to w kategoriach katalogu prawnych form działania administracji, działania władcze jednostronne. Brak było dwustronnych paneli obywatelskich, internetowych konsultacji, krótkiej debaty publicznej dotyczącej społecznej akceptacji poszczególnych środków, np. zakazu wstępu do lasów. Brak więc było dwustronnych, niewładczych środków działania administracji centralnej oraz wykorzystania potencjału partycypacyjnego podstawowych jednostek samorządu terytorialnego. Oszczędność czasu i środków finansowych nie jest argumentem w sytuacji istnienia mediów społecznościowych i błyskawicznej internetowej konsultacji za pomoca portali informacyjnych. Szersze konsultacje wstępne wzmocniłyby akceptację społeczna, zrozumienie podjętych środków, nawet ze strony tych, którzy proponowali środki nieuwzględnione. Powstaje jednak wtedy sytuacja bycia wysłuchanym, stanowiąca jeden z elementów prawa do dobrej administracji.

Doświadczenie z okresu pandemii związane z niewielkim stopniem włączenia sił społecznych w wybór środków działania administracji publicznej potwierdza tezę Michała Kasińskiego o hegemonii biurokratycznego aparatu władzy i ostrej cezurze między rządzącymi a rządzonymi, powracających mimo oficjalnego już przed laty odrzucenia zasady tzw. centralizmu demokratycznego. Należy pamiętać o ukazanym przez autora negatywnym sprzężeniu zwrotnym: osłabianie pierwiastków demokratyzmu i pluralizmu w skali państwa sprzyja bowiem podobnym procesom w jednostkach terytorialnych,

\footnotetext{
29 Szmyt (2020): $15 \mathrm{n}$.

30 Jakubek-Lalik (2019): 118.
} 
chociaż - jak wskazuje autor - również tendencja zmian ustroju władzy centralnej w kierunku monistycznym jest wspomagana przez analogiczne zmiany ustroju terenowego.

Elastyczne i odporne na wstrzasy państwo wymaga wysokiego poziomu zaufania społecznego, na kryzys tego zaufania i akceptacji społecznej jako źródła legitymacji polskiej władzy publicznej wskazuja liczne opracowania ${ }^{31}$. Jak w szczególności wskazują Konrad Maj i Krystyna Skarżyńska, bardzo niski poziom zaufania społecznego w Polsce występujący od lat miał paradoksalnie pozytywny wpływ w pierwszych miesiącach epidemii, jak podkreślają autorzy, nieufność do współobywateli skłaniała do przestrzegania rządowych zaleceń utrzymywania dystansu społecznego ${ }^{32}$. Jednak niskie zaufanie do polityków i profesjonalistów, spadająca ocena systemu służby zdrowia stanowią istotna przeszkodę w dalszych fazach kryzysu. Dopiero obecnie odczuwamy, jak kluczowa staje się współpraca i koordynacja przestrzegania bardziej złożonych zaleceń i obostrzeń. Paweł Marczewski diagnozuje popadanie w błędne koło nieufności, chaos w zarządzaniu służby zdrowia pogarsza od wielu lat niska ocenę jakości usług publicznych ${ }^{33}$. To prowadzi z kolei do obniżenia zaufania do wszystkich instytucji publicznych, w tym polityków zarówno centralnych, jak i lokalnych, co powoduje mniejszą gotowość, czego jesteśmy już świadkami, do akceptowania zaleceń władz publicznych. Skutkiem tego zjawiska staje się $\mathrm{z}$ kolei na naszych oczach pogorszenie radzenia sobie z kryzysem zdrowotnym. Dokonana przez autora analiza tego błędnego koła, a więc egzemplifikacja na przykładzie zarazy (diagnozowana już wcześniej przez Iwana Krastewa ${ }^{34}$ wspólnoty nieufnych) prowadzi do nowych wniosków.

Jak wskazano w literaturze, ogólny prospołeczny efekt nieufności zarówno uogólnionej, jak i polityków jest bardzo ograniczony ${ }^{35}$. Ostatecznie uporanie się z kryzysem zdrowotnym wymaga zaufania. Tendencje centralizacyjne może wzmacniać pozornie dodatni bilans przyrostu zaufania do konkretnych ministrów, w związku z ich adekwatnymi działaniami w warunkach pandemii. Warto jednak zwrócić uwagę na wniosek badaczy nauk społecznych, że te personalne wzrosty zaufania nie przekładają się np. na wzrost zaufania do rządu, a to powoduje gorszą responsywność wobec zaleceń, a więc gorsze sterowanie administracja publiczna, a więc mniejszą odporność państwa. Powszechnym złudzeniem może być nasuwający się wniosek, że wyjściem z błędnego koła może być edukacja obywatelska. Przekonanie to okazuje się złudzeniem, takie działania sa potrzebne, jednak decydujące sa działania władzy publicznej. Transparentne działanie, sprawiedliwy system finansowania, ogólne zapewnienie spójności społecznej

Sytuacja, w której wiążemy w polskiej doktrynie samorząd terytorialny z decentralizacją i zasadą pomocniczości, jest prawidłowa. Należy jednak zwrócić baczną uwagę na nowe tendencje w traktowaniu samorządu terytorialnego

\footnotetext{
31 Marczewski (2020).

${ }^{32}$ Maj, Skarżyńska (2020).

${ }^{33}$ Marczewski (2020).

34 Krastew (2013).

35 Marczewski (2020): 3.
} 
w doktrynie europejskiej. Chodzi tu w szczególności o traktowanie samorządu jako elementu pluralizacji (Hennecke) oraz o silniejsze niż dawniej akcentowanie bezpośredniej legitymacji demokratycznej samorządu terytorialnego. Porzucono już natomiast całkowicie istniejące przez dłuższy czas dostrzeganie pewnej sprzeczności między samorządem terytorialnym a demokracją. Podkreśla się, że właśnie samorząd terytorialny przynosi lekarstwo na podstawowy deficyt demokracji, jakim jest punktowy kontakt wyborcy tylko w momencie aktu wyborczego z wybranymi przedstawicielami. Tylko wyjątkowo, w przypadku przedterminowych wyborów lub referendum, może on ponownie wyrazić swoją wolę. Utrzymywanie stałego kontaktu z wyborcami poprzez dyżury poselskie zmieniło swój charakter i funkcję, przekształcając się w biuro interwencji w trudnych sytuacjach życiowych wyborców lub ich konfliktach $\mathrm{z}$ administracją publiczną czy sądownictwem. Zanika funkcja indywidualnych spotkań z wyborcami zatroskanymi funkcjonowaniem państwa i jego instytucji. Długo tę rolę pełniły okresowe spotkania z wyborcami w trakcie kadencji, ale i one uległy erozji zarówno pod względem skali uczestnictwa, jak i funkcji kontroli społecznej, zamieniając się często w rytualne zebrania partyjne.

Zupełnie inaczej wygląda sytuacja w samorządzie terytorialnym: jak wykazuja gruntowne studia Barbary Jaworskiej-Dębskiej ${ }^{36}$ oraz Bogdana Dolnickiego $^{37}$, Iwony Niżnik-Dobosz ${ }^{38}$ i Romana Marchaja ${ }^{39}$ czy Jakuba Szlachetko ${ }^{40}$, partycypacja okazała się forma żywą o dynamicznym rozwoju. Nie tylko przetrwały konsultacje z mieszkańcami, ale pojawiły się trzy nowe formy: budżet obywatelski ${ }^{41}$, fundusz sołecki i obywatelska inicjatywa uchwałodawcza. Regułą stały się młodzieżowe rady gminy ${ }^{42}$ i rady seniorów. Można oczywiście postulować dalszy rozwój form partycypacji społecznej w formie paneli obywatelskich oraz dostrzegać istniejace jeszcze dysfunkcje, ogólnie jednak trzeba się zgodzić z Jaworską-Dębską ${ }^{43}$, że w ciagu 30 lat funkcjonowania samorządu terytorialnego nastapił w Polsce istotny rozwój form partycypacji społecznej. Jak podkreśla autorka, ich katalog wzbogacały najpierw formy występujące w praktyce, które dopiero następnie zyskały podstawę ustawowa. To świadectwo żywej demokracji i postępującej zatem wzmocnionej legitymacji demokratycznej. Można więc postulować, aby również ten argument zajął swoje miejsca $\mathrm{w}$ doktrynie przy charakteryzowaniu istoty i roli samorządu terytorialnego w Polsce.

Dowodem na żywy i stały rozwój samorządu terytorialnego, mimo stałej presji centralizacyjnej, jest także dobrze udokumentowany w literaturze rozwój publicznoprawnych form współpracy jednostek samorządu terytorialnego. Koresponduje on dobrze z sieciowym charakterem współczesnej administra-

\footnotetext{
36 Jaworska-Dębska (2020).

${ }^{37}$ Dolnicki (2014): $15 \mathrm{n}$.

38 Niżnik-Dobosz (2014): 28-29.

${ }^{39}$ Marchaj (2016): 240-249.

40 Szlachetko (2016); (2017); Szlachetko, Szlachetko (2019).

41 Augustyniak (2014): $126 \mathrm{n}$.

42 Mędrzycki (2015): $67 \mathrm{n}$.

43 Jaworska-Dębska (2020): 62.
} 
cji europejskiej. Jednostki samorządu terytorialnego współpracują na wielu płaszczyznach, zwłaszcza pod wpływem zwiększającej się ilości zadań bez adekwatnych środków finansowych ${ }^{44}$. Jak wskazują Krystian Ziemski i Maciej Kiełbus ${ }^{45}$, jest to zarówno współpraca w związkach powiatowo-gminnych, jak i zawieranie porozumień wertykalnych oraz tworzenie związków i zawieranie porozumień w celu wspólnej obsługi jednostek organizacyjnych bezpośrednio realizujących zadania. Co prawda, jak podkreślają autorzy, regulacja prawna nowych form współpracy nie miała charakteru systemowego, a raczej przypadkowy, niekonsekwentny, ale to także jest dowód na intensyfikacje publicznoprawnej współpracy jednostek samorządu terytorialnego. Przy diagnozowanym powszechnie i wszechstronnie omówionym w literaturze głównym deficycie regulacji, jakim jest dotychczas brak pełnej regulacji metropolii i związków metropolitalnych, z wyjątkiem województwa śląskiego, również w tym zakresie można stwierdzić nowoczesną i perspektywiczną ewolucję organizacji i działania samorządu.

Istnieje przepaść między elastyczną strukturą i funkcjonowaniem samorządu, czego dowodem są między innymi powstające wciąż nowe formy współpracy samorządu terytorialnego, a sztywną i nadal poddawaną centralizacji strukturą administracji rządowej. Aparat państwowy składający się z dwóch niespójnych części o innej filozofii rządzenia nie może działać efektywnie, zwłaszcza w warunkach kryzysu. Nie chodzi przy tym o to, aby wyeliminować struktury zdekoncentrowane $\mathrm{z}$ administracji rządowej, ale aby były one racjonalnie ograniczone.

Reasumując, z trzech przedstawionych modeli optymalny dla administrowania w warunkach niepewności wydaje się model trzeci: elastycznych, współpracujących modułów administracji rządowej i samorządowej z dużym udziałem partycypacji społecznej, w praktyce jednak realizowany jest wciąż jeszcze model pierwszy, w którym celem postępującej recentralizacji wydaje się dość sztywny, maksymalnie jednolity ustrój administracji publicznej. Może on okazać się jednak kruchy wobec nagłych ciosów, ze względu na przekroczenie możliwej rozpiętości kierowania i konieczność dywersyfikacji działań w poszczególnych województwach i powiatach ${ }^{46}$.

Irena Lipowicz

Uniwersytet Kardynała Stefana Wyszyńskiego w Warszawie

i.lipowicz@uksw.edu.pl

https://orcid.org/0000-0001-6794-6683

Augustyniak, M. (2014). Budżet partycypacyjny jako instrument uczestnictwa mieszkańców w sprawowaniu władzy na poziomie lokalnym - wnioski i postulaty, [w:] I. Niżnik-Skrzydło (red.), Zastosowanie idei public governance w prawie administracyjnym. Warszawa: 10-14.

\footnotetext{
${ }^{44}$ Kudra, Karciarz (2015).

45 Ziemski, Kiełbus (2020): 94-95.

${ }^{46}$ Hennecke (2008): 37-41.
} 
Biela (2020). Koronawirus szykuje się do drugiego uderzenia, a w sanepidzie dramat. <https:// www.fakt.pl/wydarzenia/polityka/koronawirus-w-polsce-sanepid-nie-jest-przygotowany-na-druga-fale-glowny-inspektorat/lzm29k7\#slajd-1> [dostęp: 31.08.2020].

Cieślak, R. (2020). Wpływ pandemii COVID-19 na realizację projektów w modelu partnerstwa publiczno-prywatnego i koncesji na roboty budowlane lub usługi. Finanse Komunalne 3: 42-55.

Crozier, M., Friedberg, E. (1982). Człowiek i system. Ograniczenia działania systemowego. Tłum. K. Bolesta-Kukułka. Warszawa.

Dolnicki, B. (2014). Wstęp, [w:] B. Dolnicki (red.), Partycypacja społeczna w samorządzie terytorialnym. Warszawa: $15-18$.

Dolnicki, B. (red.) (2019a). Kontrola zarządcza w jednostkach samorządu terytorialnego. Warszawa.

Dolnicki, B. (red.) (2019b). Pozycja ustrojowa organów jednostek samorządu terytorialnego. Warszawa.

Dolnicki, B. (2019c). Samorząd terytorialny. Warszawa

Dziuban, E. (2019). Przejawy recentralizacji na przykładzie konstrukcji zespolenia powiatowych służb, inspekcji i straży, [w:] B. Jaworska-Dębska, E. Olejniczak-Szałowska, R. Budzisz (red.), Decentralizacja i centralizacja administracji publicznej. Współczesny wymiar w teorii i praktyce. Warszawa-Łódź: 529-547.

Florkowski, R. (2019). O potrzebie rekapitulacji, rewitalizacjii rekontekstualizacji pojęcia kontroli społecznej. Ruch Prawniczy, Ekonomiczny i Socjologiczny 81(3): 267-279.

Hennecke, H.G. (2008). Selbstverwaltung in Gemeinden und Keisen als Pluralisierungsfaktor, [w:] H.H. Trute,T. Gross, H.Ch. Roehl (red.), Allgemeines Verwaltungsrecht-Zur Tragfaehigkeit eines Konzepts. Ch. Moellers.

Jakubek-Lalik, J. (2019). Decentralizacja czy recentralizacja? Kilka uwag o regulacji konstytucyjnej i praktyce funkcjonowania samorządu terytorialnego w Polsce, [w:] B. Jaworska-Dębska, E. Olejniczak-Szałowska, R. Budzisz (red.), Decentralizacja i centralizacja administracji publicznej. Współczesny wymiar w teorii i praktyce. Warszawa-Łódź: 105-118.

Jaworska-Dębska, B. (2019). Współdziałanie jednostek samorządu terytorialnego w wybranych formach publicznoprawnych a ich samodzielność, [w:] B. Jaworska-Dębska, E. Olejniczak-Szałowska, R. Budzisz (red.), Decentralizacja i centralizacja administracji publicznej. Współczesny wymiar w teorii i praktyce. Warszawa-Łódź: 202-223.

Jaworska-Dębska, B. (2020), Partycypacja społeczna w samorządzie terytorialnym. Przemiany koncepcji prawnej i praktyki w latach 1990-2020. Zagadnienia wybrane. Samorząd Terytorialny 3: 49-64.

Kasiński, M. (2009). Monizm i pluralizm władzy lokalnej. Studium prawno-polityczne. Łódź.

Kierzkowska, J.S. (2019). Praktyczny wymiar decentralizacji oraz scentralizowania części zadań w sytuacji kryzysowej na przykładzie działań podejmowanych po nawałnicach w Borach Tucholskich, [w:] B. Jaworska-Dębska, R. Budzisz (red.), Decentralizacja i centralizacja administracji publicznej. Współczesny wymiar w teorii i praktyce. Warszawa-Łódź: 373-392.

Korczak, J. (2019). Jednolitość administracji samorządowej w państwie unitarnym, [w:] M. Stec, K. Małysa-Sulińska (red.), Unitarny charakter państwa a samorząd terytorialny. Warszawa: 192-212.

Krastew, I. (2013). Demokracja nieufnych. Tłum. M. Sutowski. Warszawa.

Krawczyk, J. (2019). Postulat deglomeracji administracji publicznej - kilka uwag natury prawnoadministracyjnej i konstytucyjnej. Przegląd Prawa Publicznego 12: 48-63.

Kruś, M. (2019). Wody Polskie - nowy podmiot w prawie wodnym, [w:] B. Jaworska-Dębska, E. Olejniczak-Szałowska, R. Budzisz (red.), Decentralizacja i centralizacja administracji publicznej. Współczesny wymiar w teorii i praktyce. Warszawa-Łódź: 615-629.

Kudra, A., Karciarz, M. (2015). Niedofinansowanie zadań zleconych w świetle wyzwań reformy samorządowej, [w:] A. Łaga, O samorządzie terytorialnym z okazji jego 25-lecia. Bielsko-Biała.

Lipowicz, I. (2019). Standardy samorządu terytorialnego, [w:] Z. Duniewska, A. Rabiega-Przyłęcka, M. Stahl (red.), Standardy współczesnej administracji i prawa administracyjnego, Warszawa-Łódź 2019: 230-247. 
Łukasiewicz, J. (2006). Zasada organizacyjnej elastyczności aparatu administracji publicznej. Warszawa.

Mager, U. (2008). Die Europaeische Verwaltung zwischen Hierarchie und Netzwerk, [w:] H.H. Trute, T. Gross, H.Ch. Roehl (red.), Allgemeines Verwaltungsrecht-Zur Tragfaehigkeit eines Konzepts. Ch.Moellers.

Maj, K., Skarżyńska, K. (2020). Społeczeństwo wobec epidemii. Raport z badań, Fundacja Batorego. <https://www.batory.org.pl/wp-content/uploads/2020/04/Badanie-spoleczenstwo-wobecepidemii-fin.pdf> [dostęp: 26.08.2020].

Marchaj, R. (2016). Samorządowe konsultacje społeczne. Warszawa.

Marczewski, P. (2020). Epidemia nieufności. Zaufanie społeczne w czasie kryzysu zdrowotnego. Fundacja Batorego. <https://www.batory.org.pl/wp-content/uploads/2020/08/Epidemia-nieufnosci.pdf> [dostęp: 26.08.2020].

Matan, A. (1996). Aspekty strukturalne administracji, [w:] E. Knosala, A. Matan, L. Zacharko, Zarys nauki administracji. Katowice.

Mażewski, L. (2020). Państwo unitarne, państwo regionalne czy w kierunku federacji? Trzy koncepcje rozwiązania problemu budowy administracyjno-terytorialnej RP. Samorząd Terytorialny $1 / 2: 7-18$.

Mędrzycki, R. (2015). Młodzieżowe organy konsultacyjne samorządu terytorialnego. Kwartalnik Prawa Publicznego 1: 67-80.

Molga, T. (2020). Koronawirus w Polsce. Będzie zmiana strategii walki z epidemia, <https:// wiadomosci.wp.pl/koronawirus-w-polsce-bedzie-zmiana-strategii-walki-z-epidemia-6547675605502656a> [dostęp: 28.08.2020].

Niżnik-Dobosz, I. (2014). Partycypacja jako pojęcie i instytucja demokratycznego państwa prawnego i prawa administracyjnego, [w:] B. Dolnicki (red.), Partycypacja społeczna w samorzadzie terytorialnym. Warszawa: 21-43.

Pegram, T. (2020). Coronavirus is a failure of global governance - now the world needs a radical transformation. <https://theconversation.com/coronavirus-is-a-failure-of-global-governance-now-the-world-needs-a-radical-transformation-136535> [dostęp: 28.08.2020].

Przedańska, J., Szwast, M. (2019). Komisja Wspólna Rządu i Samorządu Terytorialnego - w stronę upodmiotowienia samorządu terytorialnego. Ruch Prawniczy, Ekonomiczny i Socjologiczny 81(4): 165-178.

Sługocki, J. (2012). Prawo administracyjne. Zagadnienia ustrojowe. Warszawa.

Stankiewicz, R. (2019). Koordynacja w prawie administracyjnym. Warszawa.

Szlachetko, J. (2016). Udział podmiotów spoza systemu administracji publicznej w stanowieniu aktów prawa miejscowego przez organy jednostek samorządu terytorialnego. Gdańsk.

Szlachetko, J. (2017). Partycypacja społeczna w lokalnej polityce przestrzennej. Warszawa.

Szlachetko, J., Szlachetko, K. (2019). Udział interesariuszy w kształtowaniu i prowadzeniu polityki rewitalizacyjnej. Gdańsk.

Szlachetko, J. (2020). Raport Instytutu Metropolitalnego w sprawie zakresu działania i formy organizacyjnej samorządu metropolitalnego. Gdańsk.

Szmyt, A. (2020). Samorządowa podmiotowość Senatu RP - wizja zmian konstytucyjnych, [w:] K. Małysa-Sulińska, M. Stec (red.), Podmiotowość samorządu terytorialnego - ustrojowe pytania i dylematy. Warszawa: 15-34.

Wituska, E. (2019). W kierunku centralizacji państwowych służb bezpieczeństwa żywności, [w:] B. Jaworska-Dębska, E. Olejniczak-Szałowska, R. Budzisz (red.), Decentralizacja i centralizacja administracji publicznej. Współczesny wymiar w teorii i praktyce. Warszawa-Łódź: 661-677.

Ziemski, K., Karciarz, M. (2019). Zasada decentralizacji ustroju terytorialnego państwa jako wartość w świetle przepisów Konstytucji RP i prawa międzynarodowego, [w:] B. Jaworska-Dębska, E. Olejniczak-Szałowska, R. Budzisz (red.), Decentralizacja i centralizacja administracji publicznej. Współczesny wymiar w teorii i praktyce. Warszawa-Łódź 2019: 131-149.

Ziemski, K., Kiełbus, M. (2020). Ewolucja publicznoprawnych form współpracy jednostek samorządu terytorialnego. Samorząd Terytorialny 4: 82-96. 


\section{LOCAL SELF-GOVERNMENT AND GOVERNMENT ADMINISTRATION - ADMINISTRATION IN CONDITIONS OF UNCERTAINTY}

\section{Sum mary}

The year 2020, the year of the COVID-19 pandemic, has become a symbol of sudden threats that fundamentally change social and economic life. However, the pandemic is only one example of the new accumulating uncertainties, such as climate change, which are strongly affecting the public administration system. The aim of the study is to answer the question of what kind of public administration system and what legal forms of action will contribute to increasing the resistance of the State to shocks, and fostering greater flexibility of its administration. Three approaches will be presented that have their supporters in the legal sciences, namely: a centralized state that only expands expert and advisory structures in order to counter threats; a minimal state, in which the network of interaction with citizens, business entities and the administration is mainly strengthened, being one that conducts limited crisis management activities; and, lastly, the concept of a cooperative system of central and local government administration modules, with local self-government having a high level of independence, good coordination, and openness to social innovation. The author advocates the choice of the third model to create a flexible, shock-resistant state, showing the advantages of such a solution and the weaknesses of the first model, towards which the current recentralization is striving.

Keywords: local self-government; administration in conditions of uncertainty; flexibility of administrative structures; decentralization; pandemic; administrative model; government 
